\title{
PELERINAJ ŞI PUTERE ÎN RELIGIA ISLAMICĂ
}

Ioan NISTOR*

\begin{abstract}
Pilgrimage and power in Islam ${ }^{1}$. Being one of the religious practices that gather many people in the same place, the pilgrimage has been used since ancient times as a political instrument. By constructing imposing buildings in the pilgrimage sites or by their own participation, the political leaders tried on the one hand to show their power, and on the other to gain the sympathy of the crowds. Although the Islamic pilgrimage, hajj, is the youngest of the great pilgrimages, it has always been the most politicized. Taken by Muhammad from the pre-Islamic tribes, the pilgrimage to Mecca was used by the prophet as a means of unifying the Arab tribes and strengthening Islam. Nowadays, hajj is the time when the Islamic community manifests itself in the highest way, but also a subject of dispute between the different Isla mic countries that want to use its influence.
\end{abstract}

Keywords: pilgrimage, sacred place, Islam, hajj, politics.

\section{Introducere}

Pelerinajul este una din cele mai vechi practici religioase care a fost o constantă în istoria omenirii. Pentru că implică adesea mari adunări de oameni, el poate fi un puternic instrument politic și nu de puține ori a fost folosit în acest sens. Acest lucru se datorează și faptului că pelerinii au o anumită sensibilitate, ce este dezvoltată în special de călătoria sfântă în care sunt implicați, dar și de sentimentului comunional provocat de adunarea în sine.

Priest, PhD Student, Faculty of Orthodox Teology at „1 Decembrie 1918” University, Alba Iulia, Romania.

${ }^{1}$ Studiu redactat sub îndrumarea Pr. Prof. Univ. Dr. Emil Ioan Jurcan, care și-a exprimat acordul pentru publicare. 
În lucrarea de față, voi prezenta pelerinajul din lumea islamică, însă nu mă voi referi la dimensiunea sa spirituală, ci voi trata în special problema ,orizontalității” sale, adică voi arăta implicațiile sale politice.

Considerat unul din cei cinci stîlpi ai islamului, hajj a dobândit o importanță excepțională în politica mondială, ce decurge direct din statutul său religios privilegiat. Rădăcinile ferme din Coran, combinate cu un singur oraș sacru, promovează un pelerinaj global care se distinge printr-o continuitate și un cosmopolitanism fără precedent.

Creștinismul și hinduismul au și ele pelerinajele la fel de mari ca amploare și vitalitate și chiar cu o istorie mult mai veche a politizării lor, însă pentru că sunt atât de numeroase și maleabile, nu au reușit niciodată să se apropie de preeminența hajj.

\section{Unicitatea hajj-ului}

Aproape în toate religiile există obiceiul ca pelerinajul să aibă loc în anumite locuri cinstite, fie pentru că acolo se află mormintele întemeietorilor acelor religii sau ale unor sfinți, fie pentru că ele amintesc de evenimente importante din istoria lor. Pentru ca aceste locuri să devină centre de pelerinaj, trebuie să treacă ceva timp de la apariția acelei religii. Caracteristic pentru islam este faptul că pelerinajul datează din timpul lui Mohamed, el însuși oferind modelul de comportament, prin pelerinajul făcut la Mecca cu puțin timpînainte de moarte ${ }^{2}$. De aceea, religia islamică va fi marcată de practica pelerinajului pe tot parcursul istoriei sale.

Deși, întâlnim și în islam anumite pelerinaje la mormintele diferiților „sfinți”, numite ziyara ${ }^{3}$, doar pelerinajul la Mecca, hajj, este considerat adevăratul pelerinaj.

Dacă în celelalte religii, pelerinajele sunt voluntare, iar pelerinii pot alege momentul pelerinajului, precum și locurile sacre pe care să le viziteze, hajj-ul, potrivit Coranului are un caracter obligatoriu pentru toți musulmanii capabili fizic și financiar și trebuie să fie efectuat într-o singură locație și la un anumit moment. Mai mult, dacă pelerinii își aleg

\footnotetext{
${ }^{2}$ Nadia ANGHELESCU, Introducere în islam, ediția a II-a, revăzută și adăugită, Iași, Edit. Polirom, 2014, p. 43.

${ }^{3}$ Alberto VENTURA, „Islamul sunnit în perioada clasică (secolele VII-XIV)”, în Giovanni FILORAmo (coord.), Istoria religiilor, vol. III, traducere de Hanibal Stănciulescu, Iași, Edit. Polirom, 2009, p. 206.
} 
propriul fel de a-și exprima trăirea religioasă, hajj-iștii nu se bucură de această libertate și flexibilitate, ei fiind obligați să se manifeste într-un anumit fel, după modelul pelerinajului lui Mahomed. Acesta a reformat total hajj-ul, înlăturându-i influențele păgâne și punându-i la bază ascultarea necondiţionată de Allah. Potrivit majorității cercetătorilor musulmani, pelerinajul a fost decretat de profet ca obligatoriu în al șaselea an de la hegira ${ }^{4}$, moment în care el și-a rostit și ,,predica de rămas bun”, oferind ultimele pasaje ale Coranul și declarând că astfel a perfecționat religia. Sursa obligație este:

„Spune: «Allah a grăit a devăr! Urmați, așadar, religia lui Avra am cel drept întru credință, care nu a fost păgân!»Cea dintâiCasă [de închinare] ridicată pentru oameni este aceea din Bakka, cea binecuvântată și că lă uzire pentru toate lumile. În ea sunt semne limpezi, [printre care] locul unde a stat Avraam, iar acela care intră în ea este în siguranță. Este o datorie a oamenilor față de Allah [să împlinea scă] Pelerinajul la această Ca să, da că au mijloa cele pentru a ceasta. Cât despre a ceia care tăgă duiesc, Allah nu are nevoie de aceste lumi"5(Coran 3, 95-97).

Prin ritualurile sale, hajj-ul îl transportă pe pelerin atât în trecutul îndepărtat cât și în viitor. Când încercuiesc Kabba, pelerinii calcă pe urmele lui Mahomed, imită formele de cult instituite de Avraam înainte de islam, de Adam în zorii istoriei și de îngerii care înconjurau tronul lui Allah înainte de a crea universul. Privind spre celălalt pol al eternității, hajj-ul este o repetiție generală pentru Judecata finală. Îmbrăcămintea albă a pelerinului, ihramul, este simbolul sufletelor curate ce se vor ridica din morminte şi se vor așeza înaintea Judecătorului la sfârşitul veacurilor. De aceea, mulți pelerini își păstrează această îmbrăcăminte și cer familiei să fie înmormântaţi în ea, tocmai pentru a apărea la judecata finală la fel ca în timpul celor mai sfinte zile din viața lor ${ }^{6}$.

Hajj-ul este o obligație care poate fi îndeplinită numai în Mecca. Spre deosebire de Benares sau Ierusalim, Mecca nu se află în vârful unui

${ }^{4}$ As-Sayyid SABIQ, Fiqh us-Sunnah. Hajj and 'Umrah, translators Muhammad Sa'eed Dabas and M. S. Kayani, Indianapolis, American Trust Publications, 1992, p. 1.

${ }^{5}$ Coranul, traducere din limba araba, introducere şi note de George Grigore, Bucureşti, Edit. Herald, 2009.

${ }^{6}$ Robert B. BIANCHI, Guests of God: pilgrimage and politics in the Islamic World, New York, Oxford University Press, 2004, p. 39-40. 
sistem de locuri sacre, unde pelerinajele multiple oferă diferite grade ascendente de grație. Hajj-ul eclipsează toate celelalte călătorii pioase, pentru că pentru musulmani este pelerinajul lor pur și simplu.

\section{De la „pacea sacră” la „religia universală"}

Deși hajj-ul este cel mai tânăr dintre marile pelerinaje, el a fost întotdeauna cel mai politizat. Dimensiunile sale politice au existat cu multe secole înainte de Mohamed. Transformarea lui într-un pelerinaj islamic nu a făcut altceva decât să lărgească sfera de aplicare și să aprofundeze sensurile unei adunări religioase anuale, care era deja un punct de sprijin politic și economic al arabilor.

În perioada pre-islamică, Mecca era cel mai important și bogat oraș dintre orașele-state concurente prin care treceau traseele comerciale ce legau Marea Mediterană de Oceanul Indian. Acestlucru se datorează rolului său de centru religios ${ }^{7}$ al unei societăti împărțită în numeroase triburi, fără un centru politic clar. Chiar și în acele timpuri politeste, venerarea comunăa Kaabei lea determinat pe triburile arabe, aflate adesea în conflict, să lase deoparte diferențele pentru a putea săvârși ritualurile pelerinajului. Aici se întâlneau o dată pe an, moment în care erau uitate toate disputele inter-tribale și se renunța la arme, pentru a putea fi îndeplinite în liniște practicile pelerinajului ${ }^{8}$. $\mathrm{Cu}$ ocazia acestor întâlniri se organizau și târguri, în cadrul cărora aveau loc schimburi comerciale, darși schimburi de idei sau schimburi artistice. Este cazul târgului de la Ukaz de lângă Mecca, unde pe lângă schimburile comerciale, aveau loc și întreceri oratorice și poetice, cele mai reușite dintre ele fiind afișate în Templul Kaaba ${ }^{9}$.

Inima hajj-ului pre-islamic a fost această ,,pace sacră” din Mecca, ce era declarată în fiecare an în timpul pelerinajului printr-un pact făcut de triburi. Prin păstrarea statutului Meccăi ca sanctuar (haram), triburile

${ }^{7}$ Istoricii ne vorbesc că din cele mai vechi timpuri triburile arabe au „convers” spre Templul de la Mecca. Numele îl găsim menționat în Corpusul ptolemaic (secolul II d. Hr.) sub forma Makoraba, care se traduce prin „sanctuar” (Mircea Eliade, Istoria și filosofia religiilor, vol. III, traducere de Cezar Baltag, București, Edit. Științifică și Enciclopedică, 1988, p. 71).

${ }^{8}$ Alberto Ventura, „Islamul sunnit în perioada clasică (secolele VII-XIV)”, p. 203.

${ }^{9}$ Azzedine Guellouz, ,, Islamul”, în Jean Delumeau (coord.), Religiile lumii, traducere de Rodica Buburuzan, Bucureşti, Editura Humanitas, 1996, p. 313. 
reușeau în fiecare an să-și rezolve conflictele prin crearea unui forum de arbitraj și negociere pe perioada hajj-ului. Rolul diplomatic al hajj-ului pre-islamic poate fi comparat cu cel al Jocurilor Olimpice din Grecia antică. Aceastea încurajau și ele pan-elenismul în rândul orașelor-state, ce împărtășeau o cultură comună, însă se aflau într-un conflict constant ${ }^{10}$.

Dezbaterile privind rolul politic al hajj-ului, putem spune că sunt la fel de vechi ca însuși islamul. Pentru că Mahomed a întemeiat nu doar o religie, ci și un stat, este interesant modul în care hajj-ul s-a încadrat în dubla sa misiunde de profet și om politic. Dezbaterea se restrânge la a înţelege intențiile lui Mahomed. S-a uitat Mahomed în trecut sau spre viitor atunci când a stabilit hajj-ul ca și stâlp al islamului? A păstrat obiceiurile unei societăți profund conservatoare în speranța de a-i câștiga pe quraishiţii, care erau aproape să-l distrugă sau a dorit să construiască o nouă societate, total diferită de ceea ce exista până atunci, o comunitate egalitară și universală ce poate deveni o forță irezistibilă dacă idealurile hajj-ului sunt cultivate în sufletele musulmanilor din toată lumea?

Considerăm că ambele întrebări au un răspuns afirmativ și că ele nu se exclud, deși cercetătorii occidentali non-musulmani tind să subscrie poveștii compromisului, iar musulmanii viziunii idealiste a înființării unei noi societăţi. Christiaan Snouck Hurgronje ${ }^{11}$ îl consideră pe Mahomed un geniu politic, care prin decizia de a păstra hajj-ul nu a făcut altceva decât să atingă simultan mai multe obiective. Prin centrarea noului său stat pe Mecca în loc de Medina, Mohamed i-a câștigat pe foștii săi dușmani și a consolidat islamului în Arabia. De asemenea, el a obținut resurse pentru a lansa o forță unită împotriva celor mai mari puteri militare ale vremii, imperiile bizantin și persan. Când Mohamed i-a instruit pe musulmani să se roage către Mecca, în locul Ierusalimului, adepții săi puteau face o duplă alegere: puteau fi monoteiști fără a fi evrei sau creștini și puteau fi universaliști, fără a mai fi arabi. Potrivit lui Hurgronje, Mohamed a păstrat hajj-ul pentru a reuși să-i mobilizeze pe arabii, care erau foarte fideli propriilor tradiții și obiceiuri. În concepția sa, Mahomed, „,cel mai politic dintre toți profeții” a văzut în hajj un mijloc și nu un scop. Păstrând și adaptând hajj-ul la islam, Mahomed a

${ }^{10}$ Robert B. BIANCHI, Guests of God: pilgrimage and politics in the Islamic World,p. 58.

${ }^{11}$ A trăit între 8 februarie 1857 și 26 iunie 1936. A fost un cunoscut cercetător olandez al culturilor şi limbilor orientale. A petrecut şase luni la Mecca, între 1888-1889, pretinzând că e musulman. 
accentuat caracterul arab al religiei sale, făcând-o să fie plăcută unei societăţi politeiste care ținea mai mult la obiceiuri decât la zeităţi ${ }^{12}$.

\section{Hajj și politică în societatea postmodernă}

Din momentul acreditării lui de Mohamed, hajj-ul și-a manifestat în permanență influența politică, devenind pentru pelerinul musulman principala modalitate de a intra în comuniune cu musulmanii din întreaga lume și un important mijloc de consolidare a prieteniei, solidarității și ajutorării reciproce ${ }^{13}$.

Hajj-ul este momentul în care umma (comunitatea islamică) se manifestă în cel mai înalt mod. În timpul lui dispar granițele sociale și fiecare pelerin trăiește în perfectă egalitate cu ceilalți ${ }^{14}$. Majoritatea pelerinilor mărturisesc că dincolo de toate greutățile pelerinajului, capătă sentimental măreției propriei lor religii, care reușește să adune atâția oameni ${ }^{15}$.

Dacă până la mijlocul secolului al XIX-lea,numărul participanților rareori depășea 100000 de pelerini, din acel moment a început să crească ajungând la un maxim de 3,7 milioane în $2016^{16}$. Odată cu creșterea numărului pelerinilor și politizarea hajj-lui a crescut, astfel încât în zilele noastre este mai politizat ca niciodată.

Țările islamizate, una după cealaltă, au început să se folosească de influența hajj-lui. S-au creat agenții de stat ce administrează pelerinajul, politicienii încearcă să-și ademenească alegătorii promițându-le subvenții și servicii pentru hajj, băncile încearcă să-și atragă capital de la cei ce doresc să se pregătească din timp pentru hajj, iar mass-media oferă informații și consiliere cu multe luni înainte de începerea pelerinajului. Totodată, hajj-ul a început să fie folosit și pentru interesele proprii ale

${ }^{12}$ C. Snouck Hurgronje, Oeuvres choisies, présentées en français et en anglais par G. H. Bousquet et J. Schacht, Leiden, 1957, p. 171-174.

13 Ali ÜnAL, Viața în islam, traducere Mirela Cantimir, București, Rao International Publishing Company, 2010, p. 196.

14 Abdelhamid Benachenhou, Islamul, traducere din limba franceză de Constantin Codreanu, Cluj Napoca, Edit. Casa Cărții de Știință, 2016, p. 77.

${ }^{15}$ Nicolae ACHIMESCU, Universul religios în care trăim, București, Edit. Trinitas, 2013, p. 333.

16 Hajj 2016: Annual Islamic pilgrimage to Mecca in numbers, disponibil pe http://www.ibtimes.co.uk/hajj-2016-annual-islamic-pilgrimage-mecca-numbers-

1579693 (accesat la 28. 06. 2019). 
unei națiuni. Această încercare însă, de multe ori s-a întors împotriva celor care au dorit să-l folosească în acest sens și au creat multe divergențe în sânul lumii islamice. De exemplu, Arabia Saudită, în anii 1960, prin regele Faysal, a folosit hajj-ul pentru a-i influența pe oamenii de stat musulmani să adere la proiectul său de lansare a Organizației Conferinței Islamice (OIC). Deși inițial OIC a apărut ca o coaliţie împotriva adversarilor Arabiei Saudite, ea s-a transformat în cea mai importantă organizație internațională a statelor musulmane, cunoscută azi și cu numele de Organizația Cooperării Islamice (OIC), fiind a doua uniune internaţională ca mărime după Organizația Națiunilor Unite, numărând 57 de țări de pe patru continente ${ }^{17}$.

Mai târziu, succesorii lui Faysal s-au bazat pe OIC pentru a negocia un nou regim internațional pentru hajj. Noul regim al hajj-ului, nepopular și fără precedent, ce a provocat propaganda revoluționară din partea pelerinilor iranieni, presupunea un sistem de cote naționale de pelerini, în vederea reducerii deceselor provocate de supraaglomerare. Prin obținerea unui consens internațional, saudiţii au reușit să impună reforme ale hajj-ului, pe care nu ar fi îndrăznit să le adopte unilateral. Cu toate acestea, succesul lor le-a diminuat influența asupra hajj-ului, cât și asupra OIC. Au fost nevoiți să împartă puterea cu diferite țări non-arabe, dar care aveau un sistem de management al hajj-ului foarte dezvoltat: Pakistan, Malaezia, Turcia, Indonezia și Nigeria. Aceste țări s-au bucurat astfel de multe avantaje, ce leau întărit poziția în lumea islamică. Principalele puteri asiatice și africane din OIC au ajutat Arabia Saudită să se descurce cu cererea Iranului ca Riadul să renunțe la suveranitate asupra hajj-ului și a sfintelor orașe, în favoarea unei administraţii internaţionale condusă de toate statele musulmane ${ }^{18}$.

Această manageriere a hajj-ul este un permanent motiv de ceartă, mai ales între Arabia Saudită și Iran, acesta din urma acuzând autoritățile saudite că numeroși pelerini mor anual în timpul hajj-ului datorită proastei managerieri a hajj-ului. Acest conflict a culminat în anul 2015, când au decedat, potrivit autorităților saudite 2177 pelerini ${ }^{19}$. Iranul, care

${ }^{17}$ Robert B. BIANCHI, Guests of God: pilgrimage and politics in the Islamic World,p. 78-80. 18 Ibidem, p. 82-84.

19 Saudi Arabia Hajj disaster death toll rises, disponibil pe http://america.aljazeera.com/articles/2015/10/19/hajj-disaster-death-toll-over-twothousand.html (accesat la 28. 06. 2019). 
a suferit cele mai multe pierderi, 465 pelerini, susține că saudiții ascund numărul real al morților care s-ar ridica la mai mult de 4700. În 2016, Iranul le-a cerut cetățenilor să boicoteze hajj-ul și a întrerupt legăturile diplomatice cu Arabia Saudită. $\mathrm{Cu}$ toate acestea în anul următor aproximativ 80000 iranieni au participat la hajj ${ }^{20}$.

\section{Concluzii}

Pentru musulmanul simplu, hajj-ul este vârful vieții sale spirituale. Curățit de toate păcatele, el consideră că este la fel de pur ca în ziua în care s-a născut, iar dacă va muri înainte de a se întoarce acasă are asigurat paradisul. Intr-o astfel de stare, acesta uită de granițele sociale, pelerinajul devenind cea mai puternică expresie a unității și a egalităţii tuturor credincioșilor și a destinul lor comun în această lume și în următoarea. Hajj-ul este un moment de reflecție profundă, în timpul căreia pelerinii își examinează critic sufletele lor, condițiile sociale și politice din țările lor, dar și comunitatea islamică modială.

Rolul politic al pelerinajului la Mecca poate fi observat cu mult timp înainte de apariția islamului, când în timpul ,păcii sacre” ce era declarată în fiecare an în timpul pelerinajului printr-un pact făcut de triburile arabe, acestea reușeau să-și rezolve conflictele prin crearea unui forum de arbitraj și negociere.

Păstrând și adaptând hajj-ul la islam, Mahomed i-a câștigat pe foștii săi duşmani și a consolidat islamul în Arabia. De asemenea, el a obținut resurse importante pentru a lansa o forță unită împotriva celor mai mari puteri militare ale vremii.

În zilele noastre, hajj-ul este momentul în care comunitatea islamică se manifestă în cel mai înalt mod, dar și un subiect de dispută între diferitele țări islamice ce doresc să se folosească de influența acestuia.

Fuziunea explicită a religiei și a politicii în timpul hajj-ului îl face atât un pelerinaj, cât și un congres anual al islamului - o imensă adunare spirituală, care reconstituie societatea internațională musulmană, precum şi rolul ei în istorie.

Sunt și voci, însă, care consideră că politizarea hajj-ului nu face altceva decât să se opună și chiar să nege principalele valori ale acestuia.

${ }^{20}$ Robert B. BIANCHI, Guests of God: pilgrimage and politics in the Islamic World,p. 84. 
În loc să promoveze unitatea și egalitatea, aceasta îi divizeazămusulmanii după etnie, limbă, clasă, partid, regiune, sectă, gen și vârstă.

\section{Referinţe bibliografice:}

1. CORANUL, traducere din limba arabă, introducere şi note de George Grigore, Bucureşti, Edit. Herald, 2009;

2. ACHIMESCU, Nicolae, Universul religios în care trăim, București, Edit. Trinitas, 2013;

3. ANGHELESCU, Nadia, Introducere în islam, ediţia a II-a, revăzută și a dăugită, Iaşi, Edit. Polirom, 2014;

4. BENACHENHOU, Abdelhamid, Islamul, traducere din limba franceză de Constantin Codreanu, Cluj Napoca, Edit. Casa Cărții de Știință, 2016;

5. BIANCHI, Robert B., Guests of God: pilgrimage and politics in the Islamic World, New York, Oxford University Press, 2004;

6. ELIADE, Mircea, Istoria și filosofia religiilor, vol. III, traducere de Cezar Baltag, București, Edit. Științifică și Enciclopedică, 1988;

7. GuellouZ, Azzedine, „Islamul”, în Jean Delumeau (coord.), Religiile lumii, tra ducere de Rodica Buburuzan, București, Edit. Humanitas, 1996;

8. Hurgronje, C. Snouck, Oeuvres choisies, présentées en français et en angla is parG. H. Bousquet et J. Schacht, Leiden, 1957;

9. SABIQ, As-Sayyid, Fiqh us-Sunnah. Hajj and 'Umrah, translators Muhammad Sa'eed Dabas and M. S. Kayani, Indianapolis, American Trust Publications, 1992;

10. ÜNAL, Ali, Viața în islam, traducere Mirela Cantimir, București, Rao InternationalPublishing Company, 2010;

11. VENTURA, Alberto, „Islamul sunnit în perioada clasică (secolele VIIXIV)”, în Giovanni Filoramo (coord.), „Istoria religiilor”, vol. III, traducere de Haniba1 Stănciulescu, Iași, Edit. Polirom, 2009;

12.Hajj 2016: Annual Islamic pilgrimage to Mecca in numbers, disponibil pe http://www.ibtimes.co.uk/hajj-2016-annual-isla mic-pilgrimagemecca-numbers-1579693 (accesat la 28.06. 2019);

13. Saudi Arabia Hajj disaster death toll rises, disponibil pe http://a merica .aljazeera .com/articles/2015/10/19/hajj-disaster-death-tollover-two-thousand.html (accesat la 28.06. 2019). 